
\title{
of the EKMUD
}

\section{Sustained Virologic Response with Triple Therapy in a Hemodialysis Patient with Chronic HCV Infection}

\author{
Kronik HCV Enfeksiyonu Olan Bir \\ Hemodiyaliz Hastasında Üçlü Tedavi \\ ile Kalıcı Viral Yanıt
}

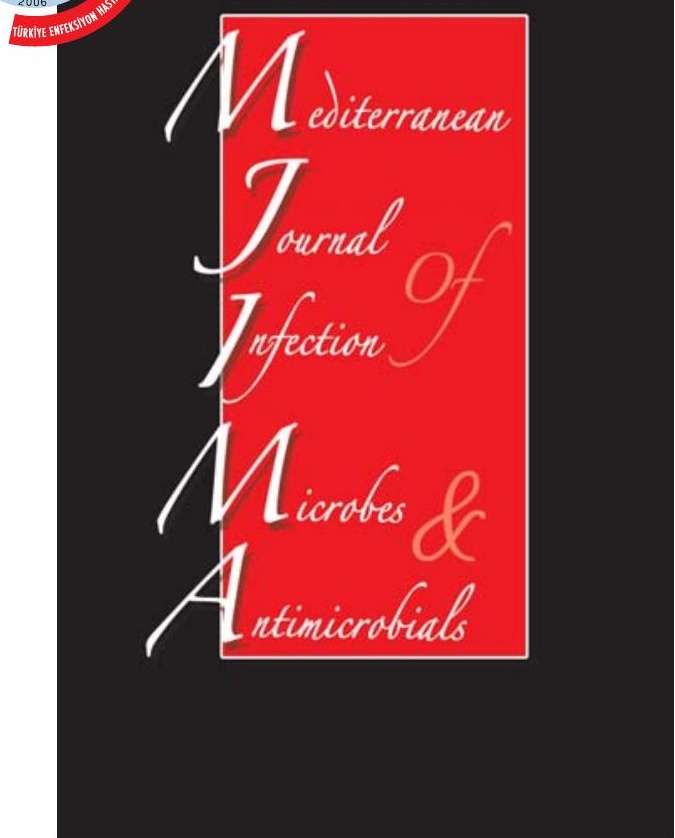

Sedat KAYGUSUZ ${ }^{1}$, Serdar GÜL ${ }^{1}$, Muhammet GÜLHAN

${ }^{1}$ Department of Infectious Diseases and Clinical Microbiology, Faculty of Medicine, Kirikkale University, Kirikkale, Turkey
${ }^{1}$ Kırıkkale Üniversitesi Tıp Fakültesi, Enfeksiyon Hastalıkları ve Klinik Mikrobiyoloji Anabilim Dalı, Kırıkkale, Türkiye

\section{ABSTRACT}

Chronic hepatitis $\mathrm{C}$ virus (HCV) infection is more prevalent and has been proven to be an independent risk factor over mortality among hemodialysis patients than normal population. Since sustained virologic response (SVR) is so beneficial and may be maintained in $90-100 \%$ of post-transplant cases, treatment of chronic HCV infection is strongly suggested for all patients undergoing renal transplantation. A 45-year-old male patient had been offered to have renal transplantation due to chronic renal failure, and referred to our clinic because of chronic HCV infection (HCV-RNA positive). He had received hemodialysis three times a week since 2007. The patient was diagnosed with chronic HCV infection fifteen years ago and was given a 48-week lasting IFN therapy in 2000 and a subsequent therapy of PEG-IFN- $\alpha 2$ a for 48 weeks in 2004. Although both therapies had yielded end of treatment responses, subsequent relapses occurred. The patient was given a combination treatment involving PEG-IFN- $\alpha 2 a$ (135 $\mu \mathrm{g} / \mathrm{wk})$ for 24 weeks and ribavirin $(200 \mathrm{mg} /$ day) for 24 weeks and telaprevir $(3 \times 750 \mathrm{mg})$ for the first 12 weeks, and a weekly control visit in our clinic. The therapy was generally well tolerated and SVR was achieved. Triple therapy might be used as a treatment option in hemodialysis patients with genotype 1 chronic HCV infections.

Key words: Hemodialysis, chronic renal failure, chronic hepatitis $C$, triple therapy

Received: 14.03.2014 • Accepted: 22.12.2014 • Published: 31.12.2014 


\section{ÖZET}

Kronik hepatit $\mathrm{C}$ virüsü (HCV) enfeksiyonu hemodiyaliz hastalarında, normal popülasyona göre daha sık görülür ve bu hastalar için mortalite açısından bağımsız bir risk faktörüdür. Bu hastalarda kalıcı viral yanıt elde edilmesi çok faydalı olduğu ve elde edilecek yanıtın transplantasyon sonrasında da \%90-100 oranında devam edeceği için transplantasyon planlanan tüm kronik HCV enfeksiyonu olan hemodiyaliz hastalarına hepatit C tedavisi kuvvetle önerilmektedir. Kırk beş yaşında beyaz, erkek hasta, kronik böbrek yetmezliği nedeniyle renal transplantasyon planlandığı ve kronik HCV enfeksiyonu olduğu için HCV tedavisi planlanması açısından kliniğimize başvurdu. Hasta 2007 yılından itibaren haftada üç kez hemodiyalize giriyordu. Hastaya 15 yıl önce kronik HCV enfeksiyonu tanısı konulmuş ve bu nedenle 2000 yılında 48 hafta interferon, 2004 yılında da 48 hafta pegile-interferon monoterapisi verilmişti. Her iki tedavi sonunda da tedavi sonu yanıt alınmasına karşın relaps gelişti. Hastaya 24 hafta pegileinterferon- $\alpha 2 a$ (135 $\mu \mathrm{g} / \mathrm{hafta}), 24$ hafta ribavirin (200 mg/gün) ve 12 hafta telaprevir $(3 \times 750 \mathrm{mg})$ tedavisi verildi ve hastaya haftalık kontrol önerildi. Tedavi genel olarak iyi tolere edildi ve kalcı viral yanıt gelişti. Genotip 1 kronik HCV enfeksiyonu olan hemodiyaliz hastalarında üçlü tedavi bir tedavi seçeneği olarak uygulanabilir.

Anahtar kelimeler: Hemodiyaliz, kronik böbrek yetmezliği, kronik hepatit C, üçlü tedavi

Geliş Tarihi: 14.03.2014 • Kabul Ediliş Tarihi: 22.12.2014 • Yayınlanma Tarihi: 31.12.2014

\section{INTRODUCTION}

Chronic hepatitis $\mathrm{C}$ virus (HCV) infection is more prevalent among hemodialysis patients than it is in normal population ${ }^{[1,2]}$. While HCV prevalence varies between $8.5-75 \%$ among hemodialysis patients worldwide, it is estimated $31.4-51 \%$ in Turkey ${ }^{[3]}$. Chronic $\mathrm{HCV}$ infection has been proved to be an independent risk factor over mortality of hemodialysis patients ${ }^{[4]}$. It has also been shown that post transplantation allograft nephropathy and diabetes mellitus are more commonly seen complications for chronic renal failure (CRF) in patients suffering from chronic HCV infection $^{[5]}$. For transplantation cases, interferon (IFN) treatments are not recommended as they increase the risk of allograft rejection. Since sustained virologic response (SVR) is so beneficial and may be maintained in $90-100 \%$ of post-transplant cases, treatment of chronic $\mathrm{HCV}$ infection is strongly suggested for all patients undergoing renal transplantation. Providing SVR should decrease the risks of chronic allograft nephropathy and de novo membrano proliferative glomerulonephritis $^{[6-8]}$.

Currently, the standard therapy approach for HCV genotype 1 patients with normal renal functions involves pegylated interferon (PEG-IFN), ribavirin, and protease inhibitor combinations ${ }^{[9]}$. However, the use of ribavirin in chronic renal failure patients may lead to anemia and it is contraindicated ${ }^{[10]}$. Monotherapy with PEG-IFN was the most suggested option in hemodialysis patients with chronic HCV infection before. However, studies in recent years have reported a com- bination therapy of IFN and low dose ribavirin as a safe option with high rates of SVR ${ }^{[11]}$. SVR rates have been reported to be as much as $56 \%$ and promising in a meta-analysis of ten studies in which a combination of PEG-IFN and ribavirin were administered to hemodialysis patients with chronic HCV infection ${ }^{[12]}$.

In May 2011, Food and Drug Administration (FDA) approved the treatment of chronic HCV genotype 1 cases by protease inhibitors (telaprevir and boceprevir) [9]. With the contribution of these agents, SVR rates have reached to as much as $65-75 \%$ among patients. Nevertheless, there are limited and inadequate data regarding the efficacy and safety of protease inhibitorsin hemodialysis patients with chronic HCV infection.

In this paper it is aimed to present a hemodialysis patient with chronic HCV infection relapsed with IFN and PEG-IFN monotherapies previously and achieved SVR with triple therapy as a first case report in Turkey

\section{CASE}

A 45-year-old Caucasian male patient had been offered to have renal transplantation due to chronic renal failure and referred to our clinic because of chronic HCV infection. The HCV-RNA level of the patient measured by real time Polymerase Chain Reaction (QUIAGEN, QI Asymphony, + Rotor Gene Q, Germany) was $9.362 \times 10^{5} / \mathrm{mm}^{3}$. He had received hemodialysis three times a week for six years due to a post-streptococcal glomerulonephritis developed in 2007. The patient was diagnosed with chronic HCV (genotype 1b) infection fifteen years ago and was given a 48-week lasting IFN (3 x 3 mu/week) therapy 
in 2000.A subsequent therapy of PEG-IFN- $\alpha 2 a$ ( $1 \mathrm{x}$ $135 \mu \mathrm{g} /$ week) for 48 weeks was also conducted in 2004. Although therapies had yielded end of treatment responses, subsequent relapses occurred.

At the first physical examination, nopathologic finding could be detected except for arteriovenous fistula on his right arm. Table 1 demonstrates the laboratory results upon first presentation. A renal USG was performed and resulted in multicystic kidney.

According to patient's history, he had not received any drugs for chronic renal failure. He only had a 6-month lasting iron replacement therapy due to deficiency in the past.

\begin{tabular}{|c|c|c|c|}
\hline AST & $: 23 \mathrm{IU} / \mathrm{L}$ & $\mathrm{Hb}$ & $: 13.7 \mathrm{~g} / \mathrm{dL}$ \\
\hline ALT & $: 16 \mathrm{IU} / \mathrm{L}$ & WBC & $: 6800 / \mathrm{mm}^{3}$ \\
\hline ALP & $: 112 \mathrm{U} / \mathrm{L}$ & PLT & $: 183.000 / \mathrm{mm}^{3}$ \\
\hline GGT & $: 179 \mathrm{U} / \mathrm{L}$ & $\mathrm{HBsAg}$ & : Negative \\
\hline T Bil & $: 0.67 \mathrm{mg} / \mathrm{dL}$ & Anti-HBsA & : Positive \\
\hline D Bil & $: 0.15 \mathrm{mg} / \mathrm{dL}$ & Anti-HIV & : Negative \\
\hline Urea & : 90 mg/dL & AFP & : $3.66 \mathrm{mg} / \mathrm{dL}$ \\
\hline \multicolumn{2}{|c|}{ Creatinin : $9.73 \mathrm{mg} / \mathrm{dL}$} & HCV-RNA & $\begin{array}{l}: 9.362 \times 10^{5} \text { copy/ } \\
\mathrm{mm}^{3} \text { (genotype: } 1 \mathrm{~b} \text { ) }\end{array}$ \\
\hline
\end{tabular}

As the patient rejected liver biopsy,it was decided to start chronic HCV infection treatment before organ transplantation. Since there is no special recommendation for the treatment duration for hemodialysis patients, we planned a combination treatment involving PEG-IFN $\alpha-2 a(135 \mu \mathrm{g} / \mathrm{wk}$ ) for 24 weeks and ribavirin (200 mg/day) for 24 weeks and telaprevir ( $3 \times 750$ $\mathrm{mg}$ ) for the first 12 weeks as recommended for genotype 1 chronic HCV patients. In addition, a weekly control visit was recommended.

The therapy was successful and well tolerated through the first four weeks without any complications. The patient experienced a rectal bleeding at the fourth week of treatment.

A grade 1 hemorrhoid was detected in physical examination and managed by local medications without any surgical application.

A progressive decrease of hemoglobin levels was monitored at the start of therapy (Figure 1). Therefore, at the fourth week, erythropoietin (EPO) $5000 \mathrm{U} / \mathrm{wk}$ was started. Hemoglobin levels reached above $10 \mathrm{~g} / \mathrm{dL}$ between the fourth and seventh weeks. Since the hemoglobin level was detected as low as $7.6 \mathrm{~g} / \mathrm{dL}$ at the eightth week, EPO dose was increased (15000 U/ $\mathrm{wk}$ ) and ribavirin dose decreased (200 mg/wk). Since

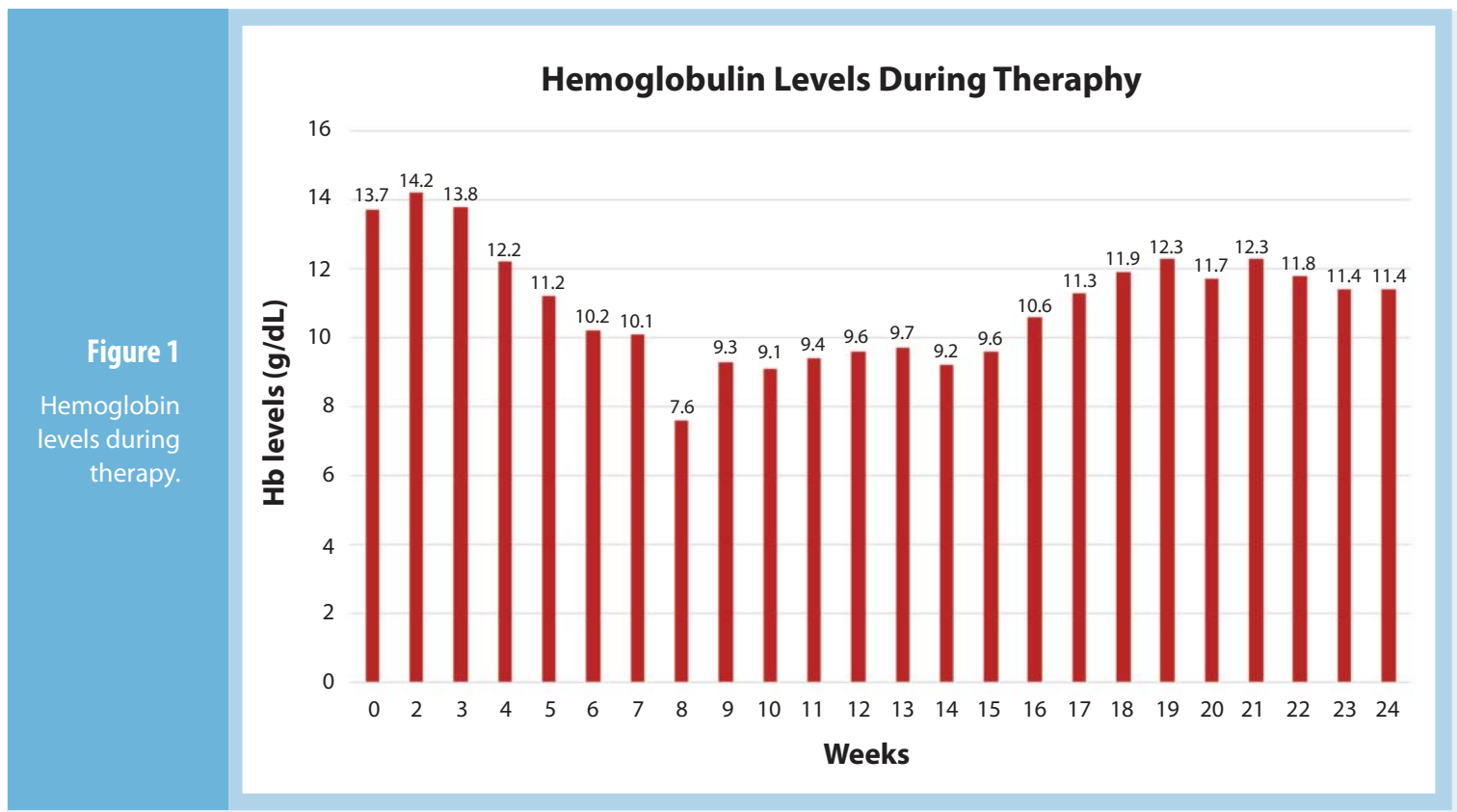


the elevation in hemoglobin levels were provided, ribavirin doses were increased gradually (200 mg per week), and by the fourteenth week, a constant dose of $200 \mathrm{mg} / \mathrm{day}$ was pursued until the end of therapy. Graphic 1 demonstrates the hemoglobin levels regarding the weeks. Telaprevir treatment was complemented to twelve weeks and ceased. EPO treatment was ceased by the seventeenth week when the hemoglobin level was above $11 \mathrm{~g} / \mathrm{dL}$. The HCV-RNA detections were found to be negative at the fourth, eighth and twelfth weeks, at the end of treatment, and twenty-four weeks after the end of the therapy. There was no decrease in thrombocyte and leukocyte levels to influence the course of the therapy.

\section{DISCUSSION}

HCV infection after renal transplantations has been proved to be an independent risk factor regarding graft rejections and mortality rates. In addition to liver diseases, extra-hepatic complications of new-onset DM, de novo allograft nephropathy, and sepsis are highly encountered among renal transplant patients with chronic HCV infections ${ }^{[13]}$. Therefore, all patients undergoing transplantation should be considered for chronic HCV treatment.

Previously, IFN monotherapy was suggested for hemodialysis patients with chronic HCV infection. Ribavirin was eliminated primarily by renal route and it was hard to clear ribavirin by hemodialysis. Since ribavirin may cause hemolytic anemia and worsen the baseline anemia of hemodialysis patients, it's usage is defined as a contraindication ${ }^{[13,14]}$. However, according tomore recent studies, low dose ribavirin and high dose EPO may be used in a safe and tolerable manner as an adjunct of IFN monotherapy. This combination can increase SVR rates in hemodialysis patients with chronic $\mathrm{HCV}$ infections from $30 \%$ up to $50 \%{ }^{[12,15]}$.

There is not a defined standard dose for ribavirin but it is usually applied as $400 \mathrm{mg} / \mathrm{day}$ to $600 \mathrm{mg} /$ week doses. Deltenre et al. have compared ribavirin doses of $1000 \mathrm{mg} /$ week in hemodialysis patients and 800 $1200 \mathrm{mg} /$ weeks in patients with normal renal functions in their study. They reported lower ribavirin serum concentrations in the first month of therapy for 1000 $\mathrm{mg}$ receiving group which disappeared later. At the end of the study, a positive correlation was detected between the first month ribavirin serum concentration and SVR rates and a dose of $1400 \mathrm{mg} /$ week ribavirin was offered as optimal for hemodialysis patients ${ }^{[5]}$.
Hakim et al. implemented a therapy of IFN monotherapy for the first month followed by ribavirin addition after four weeks in their study. The ribavirin dose was started as $200 \mathrm{mg} /$ week and increased gradually $(200 \mathrm{mg}$ with two week interval). The SVR rate of this study was reported to be $6.7 \%{ }^{[16]}$. In light of these studies, ribavirin dose was started as $200 \mathrm{mg} /$ day in our patient. However, due to a fall of $\mathrm{Hb}$ level as low as $7.6 \mathrm{~g} / \mathrm{dL}$ at the eighth week, ribavirin dose was reduced. With the recovery of $\mathrm{Hb}$ levels, we increased ribavirin doses gradually. Poordad et al. reported lower SVR rates among patients receiving $<50 \%$ of the total milligrams of ribavirin protocol assignment than those receiving $\geq$ $50 \%$. Our patient received $\geq 50 \%$ of the total ribavirin dose $^{[17]}$.

Previous studies have indicated that EPO dose may be increased up to $90.000 \mathrm{IU} /$ week in order to prevent ribavirin induced anemia ${ }^{[5]}$. Due to some cost and payment restrictions, (according to social insurance instructions) EPO could be described as 15.000 $\mathrm{IU} /$ week in the presented patient. With the rise of hemoglobin level above $11 \mathrm{~g} / \mathrm{dL}$ at the seventeenth week, EPO treatment was ceased.

Given the results of its well tolerable and pharmacokineticly safe usage by previous studies, PEG-IFN$\alpha 2 \mathrm{a}$ dose was preferred and started as $135 \mu \mathrm{g} /$ week ${ }^{[18]}$. Regarding IFN monotherapy in hemodialysis patients with chronic HCV infection, there are limited data in Turkey provided from studies of small series, and SVR rates vary between $46.1-75 \%$ in these series. Apart from our case report, we could not encounter a study subjecting ribavirin or protease inhibitor usage in hemodialysis patients in Turkey ${ }^{[3,19-22]}$.

There are limited data and experience regarding the use of telaprevir and boceprevir (protease inhibitors) in patients with chronic renal failure. However, it is supposed that renal failure leads to an insignificant pharmacokinetic interference with telaprevir ${ }^{[9]}$. In a study, $750 \mathrm{mg}$ telaprevir has been given to HCV negative patients with severe renal diseases (creatinine clearance $\leq 30 \mathrm{~mL} / \mathrm{min}$ ). As a result, mean telaprevir Cmax and AUC values have been detected to be $10-21 \%$ higher than healthy controls ${ }^{[9]}$. In our case, telaprevir was started as $750 \mathrm{mg}$ per eight hours and stopped at the twelfth week of therapy. The most common side effects of telaprevir involve rash, anemia and anorectal symptoms. Particularly cutaneous symptoms like rash may be a cause of treatment termination ${ }^{[23]}$. 
In our case, a grade 1 hemorrhoid was detected after the development of a rectal bleeding at the fourth week and managed by local topical hydrocortisone agents. Subsequently, the patient healed and reported no other anorectal complication. No cutaneous rash was detected during the follow-up of patient.

There are very limited data regarding the efficacy of triple therapy in hemodialysis patients with chronic HCV infection. According to the sole study we found in the international literature, after triple therapy, early virologic response was provided in three of four patients. These chronic HCV patients had been previously treated and not responded ${ }^{[9]}$. Arapid, early and sustained virologic response was also achieved in our patient. Triple therapy was also well tolerated.

In conclusion triple therapy might be used as a treatment option in hemodialysis patients with genotype 1 chronic HCV infections. Nevertheless, there is a need for more comprehensive studies in order to reveal safety and efficacy of triple therapy in that patient group.

\section{REFERENCES}

1. Tang S, Lai KN. Chronic viral hepatitis in hemodialysis patients. Hemodial Int 2005; 9: 169-79.

2. Furusyo $N$, Hayashi J, Kanamoto-Tanaka $Y$, Ariyama I, Etoh Y, Shigematsu M, et al. Liver damage in hemodialysis patients with hepatitis $C$ virus viremia: a prospective 10-year study. Dig Dis Sci 2000; 45: 2221-8.

3. Kose S, Gurkan A, Akman F, Kelesoglu M, Uner U. Treatment of hepatitis $C$ in hemodialysis patients using pegylated interferon $a-2 a$ in Turkey. $J$ Gastroenterol 2009; 44: 353-8.

4. Fabrizi F, Takkouche B, Lunghi G, Dixit V, Messa P, Martin $P$. The impact of hepatitis $C$ virus on survival in dialysis patients: Meta-analysis of observational studies. J Viral Hepat 2007; 14: 697-703.

5. Deltenre P, Moreno C, Tran A, Olliver I, Provot F, Stanke $F$, et al. Anti-viral therapy in haemodialysed HCV patients: efficacy, tolerance and treatment strategy. Aliment Pharmacol Ther 2011; 34: 454-61.

6. Mahmoud IM, Sobh MA, El-Habashi AF et al: Interferon therapy in hemodialysis patients with chronic hepatitis C: study of tolerance, efficacy and posttransplantation course. Nephron Clin Pract 2005; 100: 133-9.

7. Fabrizi F, Lunghi G, Ganeshan SV, Martin P, Messa $P$. Hepatitis $C$ virus infection and the dialysis patient. Semin Dial 2007; 20: 416-22.
8. Meyers CM, Seeff LB, Stehman-Breen CO, et al. Hepatitis $C$ and renal disease: an update. $A m \mathrm{~J}$ Kidney Dis 2003; 42: 631-57.

9. Dumortier J, Guillaud O, Gagnieu MC, Janbon B, Juillard L, Morelon E, et al. Anti-viral triple therapy in haemodialysed HCV patients: Is it feasible? J Clin Virol 2013; 56: 146-9.

10. Fabrizi F, Lunghi G, Dixit V, Martin P. Meta-analysis: anti-viral therapy of hepatitis $C$ virus-related liver disease in renal transplant patients. Aliment Pharmacol Ther 2006; 24: 1413-22.

11. Ghany MG, Strader DB, Thomas DL, Seeff LB. Diagnosis, management and treatment of hepatitis C: an update. Hepatology 2009; 49: 1335-74.

12. Fabrizi F, Dixit V, Martin P, Messa P. Combined antiviral therapy of hepatitis $C$ virus in dialysis patients: meta-analysis of clinical trials. J Viral Hepat 2011; 18: 263-9.

13. Carrion AF, Fabrizi F, Martin P. Should ribavirin be used to treat hepatitis $C$ in dialysis patients? Semin Dialysis 2011; 24: 272-4.

14. Alsaran K, Sabry A, Shaheen N. Pegylated interferon alpha-2a for treatment of chronic HCV infection in hemodialysis patients: a single Saudi center experience. Int Urol Nephrol 2011; 43: 865-73.

15. Gupta SK, Kantesarina B, Glue P. Pharmacokinetics, safety and tolerability of ribavirin in hemodialysisdependent patients. Eur J Clin Pharmacol 2012; 68: 415-8.

16. Hakim W, Sheikh S, Inayat I, Caldwell C, Smith D, Lorber M, et al. HCV response in patients with end stage renal disease treated with combination pegylated interferon $a-2 a$ and ribavirin. J Clin Gastroenterol 2009; 43: 477-81.

17. Poordad F, Lawitz E, Reddy R, Afdhal NH, Hezode $C$, Zeuzem $S$, et al. Effects of ribavirin dose reduction vs. erythropoietin for boceprevir-related anemia in patients with chronic hepatitis $C$ virus genotype 1 infection-A randomized trial. Gastroenterology 2013; 145: 1035-44.

18. Rendina M, Schena A, Castellaneta NM, Losito F, Amoruso AC, Stallone G, et al. The treatment of chronic hepatitis $C$ with peginterferon alfa-2a (40 $k D a)$ plus ribavirin in haemodialysed patients awaiting renal transplant. J Hepatol 2007; 46: 768-74.

19. Akhan SC, Kalender B, Ruzgar M. The response to pegylated interferon alpha $2 a$ in haemodialysis patients with hepatitis $C$ virus infection. Infection 2008; 36: 341-4.

20. Ayaz C, Celen MK, Yuce UN, Geyik MF: Efficacy and safety of pegylated-interferon a-2a in hemodialysis patients with chronic hepatitis $C$. World $J$ Gastroenterol 2008; 14: 255-9. 
21. Kose S, Senger SS, Ersan G, Cavdar G. Virological responses of pegylated interferon alpha-2a treatment in hemodialysis patients infected with hepatitis C. Clin Exp Nephrol 2013; 17: 115-9.

22. Kokoglu OM, Ucmak H, Hosoglu S, Cetinkaya A, Kantarceken B, Buyukbese MA, et al. Efficacy and tolerability of pegylated-interferon alpha-2a in hemodialysis patients with chronic hepatitis $C . J$ Gastroenterol Hepatol 2006; 21: 575-80.

23. Gaetano JN, Reau N: Hepatitis C. management of side effects in the era of direct-acting antivirals. Curr Gastroenterol Rep 2013; 15: 305.
Yazışma Adresi /Address for Correspondence

Dr. Sedat KAYGUSUZ

Kırıkkale Üniversitesi Tıp Fakültesi

Enfeksiyon Hastalıkları ve Klinik Mikrobiyoloji Anabilim Dalı

Kırıkkale/Türkiye

E-posta: sedatkaygusuz@msn.com 